\title{
Analisis Perilaku Konsumen Terhadap Pembelian Ayam Broiler dan Ayam Buras di Desa Gareccing Kecamatan Sinjai Selatan Kabupaten Sinjai
}

\author{
The Analysis of Consumer Behavior to Purchase are Broiler and Buras Chicken \\ in Gareccing Village Sinjai Selatan Subdistrict Sinjai Regency
}

\author{
Astati*, Muhammad Nur Hidayat, Andi Suarda, Ahmad Alim \\ Jurusan Ilmu Peternakan Fakultas Sains dan Teknologi \\ Universitas Islam Negeri Alauddin Makassar \\ *Korespondensi Email: astati@uin-alauddin.ac.id
}

\begin{abstract}
ABSTRAK
Tujuan dari penelitian ini adalah untuk mengetahui karakteristik konsumen dalam membeli ayam broiler dan ayam buras dan mengetahui faktor-faktor yang mempengaruhi perilaku konsumen dalam keputusan pembelianayam broiler dan ayam buras. Penelitian ini dilaksanakan pada bulan April sampai Juni 2016 di Desa Gareccing Kecamatan Sinjai Selatan Kabupaten Sinjai, denganmengambil sampel sebanyak 85 responden. Analisis data yang digunakan dalam penelitian ini adalah Analisis Regresi Berganda. Hasil penelitian menunjukkan bahwa tingkat pendidikan dan harga ayamtidak memberikan pengaruh yang signifikan terhadap frekuensi pembelian ayambroiler. Namun, pendapatan memberikan pengaruh yang signifikan terhadapfrekuensi pembelian ayam broiler di Desa Gareccing Kecamatan Sinjai SelatanKabupaten Sinjai, sedangkan faktor-faktor yang memberikan pengaruh signifikan terhadap frekuensi pembelian ayam buras diberikan oleh variabel pendapatan danharga ayam di Desa Gareccing Kecamatan Sinjai Selatan Kabupaten Sinjai.
\end{abstract}

Kata kunci: Broiler, Buras, Keputusan Pembelian, Perilaku Konsumen,

\begin{abstract}
The role of the research is to knowing the characteristic of the consumer in buying broiler and buras and to knowing some factors that influence the act of the consumer to decide in buying broiler chicken and local chicken. The research was conducted in April until Juni 2016, by taking samples of as many as 85 in the village of Gareccing, Sinjai. The analysis of the data was used in this research that multiple regression analysis.Research results showed that the level of education, income, and the price of chicken together give not a real impact on the frequency of purchase of local chicken in the village Gareccing, District of South Sinjai, Sinjai Regency. While in broiler chickens, education levels and the price of chicken does not have a significant effect, but income have a significant effect on the frequency of purchase of broiler chickens in the village Gareccing, District of South Sinjai, Sinjai Regency.
\end{abstract}

Keywords: Broiler, Costumer Behavior, Native Chicken 
Astati dkk., $\mid 11$

JiiP Volume 4 Nomor 1: 10-22, Juni 2018

\section{PENDAHULUAN}

Daging ayam merupakan jenis makanan bergizi yang sangat popular di kalangan masyarakat yang bermanfaat sebagai sumber protein. Hampir semua jenis lapisan masyarakat dapat mengkonsumsi jenis makanan ini sebagai sumber protein. Hal ini disebabkan daging ayam merupakan salah satu bentuk makanan yang mudah diperoleh dan mudah pula cara pengolahannya. Selain itu, daging ayam merupakan jenis bahan makanan yang selalu dibutuhkan dan dikonsumsi secara luas oleh masyarakat, sehingga kebutuhan daging ayam juga akan terus meningkat.

Terdapat berbagai macam jenis daging ayam yang dikonsumsi masyarakat diantaranya ayam buras (Non-Perebred Chicken), ayam ras pedaging (Broiler Chicken) serta ayam ras petelur (Laying Pullet Chicken). Masyarakat dalam mengkonsumsi daging ayam selalu memilih diantara 3 jenis daging ayam tersebut yang tersedia di pasaran. Perbedaan dari sisi cita rasa dan harga merupakan salah satu pertimbangan masyarakat dalam mengkonsumsi daging ayam. Salah satu daging ayam yang digemari masyarakat adalah daging ayam ras pedaging (Broiler Chicken) dan ayam buras (Non-Perebred Chicken).

Ayam ras pedaging disebut juga broiler merupakan jenis ternak yang memiliki daya beli yang tinggi di kalangan masyarakat. Ayam broiler merupakan jenis ras unggulan hasil persilangan dari bangsa-bangsa ayam yang memiliki daya produktivitas tinggi, terutama dalam memproduksi daging ayam sedangkan ayam buras atau biasa dikenal dengan ayam kampung merupakan ayam hasil peliharaan kebanyakan orang yang tinggal di daerahdaerah pedesaan. Ayam kampung adalah ayam lokal Indonesia yang berasal dari ayam hutan merah yang telah dijinakkan. Akibat dari proses evolusi dan domestikasi, maka terciptalah ayam kampung yang telah beradaptasi dengan lingkungan sekitarnya, sehingga lebih tahan terhadap penyakit dan cuaca dibandingkan dengan ayam ras (Anonim, 2015).

Desa Gareccing merupakan salah satu pengkonsumsi daging ayam serta mayoritas warga adalah peternak. Berdasarkan data yang diperoleh dari Dinas Peternakan Kabupaten Sinjai khususnya di Kecamatan Sinjai Selatan Desa Gareccing, peternak ayam buras mencapai $90 \%$, sedangkan untuk peternak ayam broiler sekitar $45 \%$. Melihat perbandingan peternak ayam buras dan ayam broiler adalah 2:1, namum dalam hal mengkonsumsi daging ayam warga masih banyak mengkonsumsi ayam broiler. Hal ini disebabkan kebanyakan warga menjual ayam peliharaannya (ayam buras) kemudian membeli ayam broiler. 
Data di atas dapat diketahui bahwa produksi daging dari ayam ras pedaging (broiler) dan ayam buras merupakan produksi terbesar di Desa Gareccing. Konsumen cenderung sangat selektif dalam mengkonsumsi bahan makanan. Tingginya produksi ayam ras pedaging dan ayam buras tidak lepas dari besarnya permintaan masyarakat terhadap daging ayam broiler dan ayam buras.

Konsumen mempunyai karakteristik yang berbeda-beda dalam setiap pembelian daging ayam broiler maupun ayam buras (Burhanuddin, 2011). Berbagai dasar pertimbangan konsumen yang menjadi alasan konsumen melakukan pengambilan keputusan terhadap pembelian ayam broiler maupun ayam buras. Atas dasar latar belakang di atas peneliti ingin mengetahui lebih jauh tentang analisis faktor-faktor yang mempengaruhi perilaku konsumen terhadap pembelian ayam broiler dan ayam buras di Desa Gareccing Kecamatan Sinjai Selatan Kabupaten Sinjai. Adapun tujuan Penelitian ini yaitu untuk mengetahui karakteristik konsumen terhadap pembelian ayam broiler dan ayam buras di Desa Gareccing Kecamatan Sinjai Selatan Kabupaten Sinjai. Serta untuk mengetahui faktor-faktor yang mempengaruhi perilaku konsumen terhadap pembelian ayam broiler dan ayam buras di Desa Gareccing Kecamatan Sinjai Selatan Kabupaten Sinjai.

\section{METODE}

Daerah yang menjadi sasaran penelitian adalah Desa Gareccing Kecamatan Sinjai Selatan Kabupaten Sinjai. Pemilihan lokasi dilakukan secara sengaja dengan pertimbangan bahwa warga atau masyarakat yang menjadi objek dalam penelitian ini merupakan konsumen daging ayam broiler dan ayam buras.

\section{Populasi dan Sampel}

Populasi dalam penelitian ini adalah semua kepala keluarga yang ada di Desa Gareccing Kecamatan Sinjai Selatan Kabupaten Sinjai berjumlah 592. Berhubung dengan luasnya cakupan daerah penelitian maka dilakukan pengambilan sampel sebesar 85 kepala keluarga. Untuk menentukan besarnya sampel, maka dilakukan dengan menggunakan statistik deskriptif dengan menggunakan rumus Slovin, yaitu (Umar, 2003): 


$$
n=\frac{N}{1+N(e)^{2}}
$$

Dimana:

$\mathrm{n}=$ ukuran sampel

$\mathrm{N}=$ ukuran populasi

e $=$ standar error (batas ketelitian) 10\%

\section{Analisis Data}

Untuk mengetahui perilaku konsumen terhadap pembelian ayam broiler dan ayam buras di Desa Gareccing Kecamatan Sinjai Selatan Kabupaten Sinjai digunakan skala interval dengan langkah-langkah sebagai berikut:

1. Penentuan kemungkinan skor tertinggi dan terendah:

- Ayam boiler

Skor tertinggi $=5 \times 43=215$

Skor terendah $=1 \times 43=43$

- Ayam buras

Skor tertinggi $=5 \times 42=210$

Skor terendah $=1 \times 42=42$

2. Rentang skala

- $\quad$ Ayam boiler $=\frac{m-n}{b}=\frac{215-43}{5}=\frac{172}{5}=34,4$

- $\quad$ Ayam buras $=\frac{m-n}{b}=\frac{210-42}{5}=\frac{168}{5}=33,6$

3. Interpretasi terhadap skor perilaku

- Ayam boiler

$43-77,4=$ Sangat Tidak Setuju

$78,4-111,8=$ Tidak Setuju

$112,8-146,2=$ Biasa

$147,2-180,6=$ Setuju

$181,6-215=$ Sangat Setuju

- Ayam buras

$42-75,6=$ Sangat Tidak Setuju

76,6-109,2 = Tidak Setuju

$110,2-142,8=$ Biasa 


$$
\begin{array}{ll}
143,8-176,4 & =\text { Setuju } \\
177,4-210 & =\text { Sangat Setuju }
\end{array}
$$

Sedangkan untuk mengetahui faktor-faktor yang mempengaruhi frekuensi pembelian ayam broiler dan ayam buras digunakan analisis Regresi Linear Berganda dengan persamaan sebagai berikut:

$$
\mathrm{Y}=\mathrm{a}+\mathrm{b} 1 \mathrm{X} 1+\mathrm{b} 2 \mathrm{X} 2+\mathrm{b} 3 \mathrm{X} 3+\mathrm{e}
$$

Dimana

$\mathrm{a}=\quad$ Konstanta

$\mathrm{b}=\quad$ Koefisien Regresi

$\mathrm{X} 1=$ Tingkat Pendidikan (Tahun Sukses Pendidikan)

$\mathrm{X} 2=$ Pendapatan $($ Rupiah/Bulan)

$\mathrm{X} 3=$ Harga (Rupiah/Ekor)

$\mathrm{e}=$ Tingkat Kesalahan

\section{HASIL DAN PEMBAHASAN}

\section{Perilaku Konsumen terhadap Pembelian Ayam Broiler dan Ayam Buras}

Perilaku konsumen merupakan hal-hal yang mendasari konsumen untuk membuat keputusan pembelian. Adapun atribut yang digunakan untuk mengukur tingkat perilaku konsumen terhadap pembelian ayam broiler dan ayam buras di Desa Gareccing Kecamatan Sinjai Selatan Kabupaten Sinjai adalah warna daging, tekstur daging, bau daging, dan harga daging.

\section{Warna Daging}

Warna daging merupakan salah satu faktor penting dalam keputusan pembelian. Kualitas daging segar dapat dilihat dari warna daging itu sendiri. Warna daging pada daging segar disebabkan oleh adanya pigmen merah keunguan yang disebut myoglobin yang berikatan dengan oksigen yang struktur kimianya hampir sama dengan haemoglobin. Timbulnya warna coklat menandakan bahwa daging telah terlalu lama terkena udara bebas, sehingga menjadi rusak (Astawan, 2004).

Perilaku konsumen terhadap pembelian daging yang berkualitas adalah warna daging ayam yang segar dapat dilihat pada Tabel 1. Pada Tabel. 1 memperlihatkan total bobot perilaku konsumen terhadap warna daging ayam broiler dan warna daging ayam buras adalah 167 yang berada pada interval $(147,2-180,6)$ dan 153 berada pada interval 
(143,8-176,4). Skor tersebut menunjukkan bahwa tanggapan konsumen setuju terhadap warna daging ayam broiler dan ayam buras yang segar. Hal ini disebabkan karena konsumen dalam melakukan pembelian daging ayam sangat bergantung pada warna daging ayam yang berkualitas.

Tabel 1. Perilaku Konsumen terhadap Warna Daging Ayam Broiler dan Ayam Buras di Desa Gareccing Kecamatan Sinjai Selatan Kabupaten Sinjai

\begin{tabular}{ccccccc}
\hline \multirow{2}{*}{ No } & \multirow{2}{*}{ Uraian } & Skor & \multicolumn{2}{c}{ Ayam Broiler } & \multicolumn{2}{c}{ Ayam Buras } \\
\cline { 4 - 7 } & & 5 & 8 & 40 & 19 & 95 \\
Jumlah & Bobot & $\begin{array}{c}\text { Jumlah } \\
\text { (Orang) }\end{array}$ & Bobot \\
\hline 1 & Sangat Setuju & 5 & 20 & 80 & 17 & 68 \\
2 & Setuju & 3 & 9 & 27 & 6 & 18 \\
3 & Biasa & 2 & 4 & 16 & 0 & 0 \\
4 & Tidak Setuju & 2 & 4 & 0 & 0 \\
5 & Sangat Tidak Setuju & 1 & 43 & 167 & 42 & 153 \\
\hline & Skor Jawaban & & & 3,9 & & 4,3 \\
\hline
\end{tabular}

Sumber: Data Primer setelah Diolah, 2016.

\section{Bau Daging}

Bau daging adalah salah satu faktor yang mempengaruhi perilaku konsumen dalam pembelian daging yang akan dikonsumsi. Kebusukan akan kerusakan daging ditandai oleh terbentuknya senyawa-senyawa berbau busuk seperti amonia, H2s, indol, dan amin, yang merupakan hasil pemecahan protein oleh mikroorganisme (Anonim, 2015). Untuk mengetahui perilaku konsumen/responden terhadap bau daging ayam broiler dan ayam buras dapat dilihat pada Tabel 2.

Tabel 2. Perilaku Konsumen terhadap Bau Daging Ayam Broiler dan Ayam Buras di Desa Gareccing Kecamatan Sinjai Selatan Kabupaten Sinjai

\begin{tabular}{|c|c|c|c|c|c|c|}
\hline \multirow[b]{2}{*}{ No. } & \multirow[b]{2}{*}{ Uraian } & \multirow[b]{2}{*}{ Skor } & \multicolumn{2}{|c|}{ Ayam Broiler } & \multicolumn{2}{|c|}{ Ayam Buras } \\
\hline & & & $\begin{array}{l}\text { Jumlah } \\
\text { (Orang) }\end{array}$ & Bobot & $\begin{array}{l}\text { Jumlah } \\
\text { (Orang) }\end{array}$ & Bobot \\
\hline 1. & Sangat Setuju & 5 & 5 & 25 & 3 & 15 \\
\hline 2. & Setuju & 4 & 16 & 64 & 17 & 68 \\
\hline 3. & Biasa & 3 & 15 & 45 & 12 & 36 \\
\hline 4. & Tidak Setuju & 2 & 7 & 28 & 7 & 28 \\
\hline 5. & Sangat Tidak Setuju & 1 & 0 & 0 & 3 & 6 \\
\hline & Skor Jawaban & & 43 & 162 & 42 & 153 \\
\hline & Persentase (\%) & & & 3,8 & & 3,6 \\
\hline
\end{tabular}

Sumber: Data Primer setelah Diolah, 2016. 
Berdasarkan Tabel 2. di atas, perilaku konsumen terhadap bau daging ayam broiler dan ayam buras, sebagian besar konsumen menanggapi setuju terhadap daging ayam yang tidak berbau amis yaitu sebanyak 16 dan 17 orang, sedangkan sebagian kecil yang sangat setuju yaitu 5 dan 3 orang. Sementara total bobot perilaku konsumen terhadap daging ayam yang tidak berbau amis adalah sebesar 162yang berada pada interval $(147,2-180,6)$ dan 153 berada pada interval $(143,8-176,4)$. Nilai tersebut menunjukkan bahwa konsumen setuju akan bau daging ayam yang tidak amis.

\section{Tekstur Daging}

Tekstur daging merupakan penentu perilaku konsumen dalam pembelian daging ayam broiler dan ayam buras untuk kebutuhan konsumen. Perilaku konsumen terhadap tekstur daging yang baik adalah licin/mengkilap. Perilaku konsumen/responden terhadap tekstur daging ayam broiler dan ayam buras dapat dilihat pada Tabel 3.

Berdasarkan Tabel 3., terlihat bahwa perilaku konsumen terhadap tekstur daging ayam broiler yang licin/mengkilap, sebagian konsumen menanggapi biasa yaitu sebanyak 13 dan 19 orang, sedangkan sebagian kecil menyatakan sangat setuju yaitu sebanyak 2 dan 1 orang. Sementara total bobot perilaku konsumen terhadap tekstur daging ayam broiler yang licin/mengkilap adalah sebesar 151 yang berada pada interval (147,2-180,6) dan 144 berada pada interval $(143,8-176,4)$. Nilai tersebut menunjukkan bahwa konsumen setuju akan tekstur daging ayam yang licin/mengkilap.

Tabel 3. Perilaku Konsumen terhadap Tekstur Daging Ayam Broiler dan Ayam Buras di Desa Gareccing Kecamatan Sinjai Selatan Kabupaten Sinjai

\begin{tabular}{ccccccc}
\hline \multirow{2}{*}{ No. } & \multirow{2}{*}{ Uraian } & Skor & \multicolumn{2}{c}{ Ayam Broiler } & \multicolumn{2}{c}{ Ayam Buras } \\
\cline { 3 - 6 } & & 5 & 2 & 10 & 1 & 5 \\
Jumlah & Bobot & $\begin{array}{c}\text { Jumlah } \\
\text { (Orang) }\end{array}$ & Bobot \\
\hline 1. & Sangat Setuju & 4 & 11 & 39 & 13 & 52 \\
2. & Setuju & 3 & 13 & 48 & 19 & 57 \\
3. & Biasa & 2 & 12 & 44 & 6 & 24 \\
4. & Tidak Setuju & 5 & 10 & 3 & 6 \\
5. & Sangat Tidak Setuju & 1 & 43 & 151 & 42 & 144 \\
\hline & Skor Jawaban & & & 3,5 & & 3,4 \\
\hline
\end{tabular}

Sumber: Data Primer setelah Diolah, 2016.

\section{Harga Daging}

Harga suatu daging merupakan salah satu penentu atas besarnya permintaan. Harga yang murah umumnya akan dapat menjadi salah satu faktor pendorong seseorang dalam 
mengambil keputusan pembelian suatu daging. Akan tetapi secara psikologis, harga yang murah dapat memberikan dampak negatif bagi peternak karena image harga yang murah dapat menjadi indikator suatu daging yang kurang layak dikonsumsi (Umar, 2003). Pada Tabel 4 berikut ini akan dijelaskan tentang perilaku konsumen/responden terhadap harga daging ayam broiler dan ayam buras.

Tabel 4. Perilaku Konsumen terhadap Harga Daging Ayam Broiler dan Ayam Buras di Desa Gareccing Kecamatan Sinjai Selatan Kabupaten Sinjai

\begin{tabular}{ccccccc}
\hline No. & Uraian & Skor & \multicolumn{2}{c}{ Ayam Broiler } & \multicolumn{2}{c}{ Ayam Buras } \\
\cline { 3 - 6 } & & & $\begin{array}{c}\text { Jumlah } \\
\text { (Orang) }\end{array}$ & Bobot & $\begin{array}{c}\text { Jumlah } \\
\text { (Orang) }\end{array}$ & Bobot \\
\hline 1. & Sangat Setuju & 5 & 14 & 70 & 13 & 65 \\
2. & Setuju & 4 & 16 & 64 & 11 & 44 \\
3. & Biasa & 3 & 9 & 27 & 13 & 39 \\
4. & Tidak Setuju & 2 & 3 & 12 & 4 & 16 \\
5. & Sangat Tidak Setuju & 1 & 1 & 2 & 1 & 2 \\
\hline & Skor Jawaban & & 43 & 175 & 42 & 166 \\
& Persentase (\%) & & & 34,1 & & 4,0 \\
\hline
\end{tabular}

Sumber: Data Primer setelah Diolah, 2016.

Berdasarkan Tabel 4. di atas, terlihat bahwa perilaku konsumen/responden terhadap harga daging ayam adalah yang harganya terjangkau. Sebagian besar konsumen menanggapi setuju terhadap daging ayam yang harganya terjangkau yaitu sebanyak 16 dan 11 orang, sedangkan sebagian menyatakan sangat setuju yaitu sebanyak 14 dan 13 orang. Sementara total bobot tingkat perilaku konsumen terhadap harga daging ayam yang terjangkau adalah sebesar 175 yang berada pada interval $(147,2-180,6)$ dan 166 berada pada interval $(143,8-176,4)$. Nilai tersebut menunjukkan bahwa konsumen setuju akan daging ayam yang harganya terjangkau.

\section{Analisis Faktor-faktor yang Memperngaruhi Pembelian Ayam Broiler dan Ayam Buras}

Model yang digunakan untuk menganalisis faktor-faktor yang mempengaruhi keputusan pembelan ayam broiler dan ayam buras adalah analisis regresi. Variabel terikat digunakan yang dalam penelitian ini adalah frekuensi pembelian ayam (kali/bulan). Terdapat dua variabel terikat yang digunakan yakni frekuensi pembelian ayam broiler $\left(\mathrm{Y}_{1}\right)$ dan frekuensi pembelian ayam buras $\left(\mathrm{Y}_{2}\right)$. Variabel bebas (variabel $\mathrm{X}$ ) yang diduga berpengaruh adalah tingkat pendidikan (tahun sukses pendidikan), pendapatan (rupiah/bulan), dan harga ayam (rupiah/kg). 
Tabel 5. Hasil Analisis Regresi Linear Berganda Faktor-faktor yang Mempengaruhi Pembelian Ayam Broiler di Desa Gareccing Kecamatan Sinjai Selatan Kabupaten Sinjai

\begin{tabular}{lcrrl}
\hline \multicolumn{1}{c}{ Variabel Penelitian } & \multicolumn{1}{c}{$\begin{array}{c}\text { Koefisien } \\
\text { Regresi }\end{array}$} & THitung & $\begin{array}{c}\text { Nilai } \\
\text { Signifikansi }\end{array}$ & Keterangan \\
\hline Tingkat Pendidikan & $-0,02$ & $-0,697$ & 0,490 & Tidak Signifikan \\
Pendapatan & 0,0000004821 & 3,137 & 0,003 & Signifikan \\
Harga & 0,00002713 & 1,7 & 0,097 & Tidak Signifikan \\
\hline $\mathrm{R}^{2}$ & $=0,577$ & & & \\
Constanta & $=-0,191$ & & & \\
Adjusted R Square & $=0,544$ & & & \\
\hline $\mathrm{F}_{\text {Hitung }}$ & $=17,715$ & $\mathrm{~F}_{\text {Tabel }}$ & $=2,852$ & \\
$\mathrm{~T}_{\text {Tabel }}$ & $=2,024$ & & & \\
$\mathrm{a}=0,05$ & & & & \\
\hline
\end{tabular}

Sumber: Hasil Analisis, 2016.

Berdasarkan Tabel 5., maka dapat dibentuk suatu persamaan regresi linier berganda sebagai berikut:

$$
Y=-0,191-0,02 X_{1}+0,0000004821 X 2+0,00002713 X 3
$$

Dari persamaan regresi di atas diperoleh nilai konstanta sebesar -0,191. Hal ini menunjukkan bahwa jika tidak ada pengaruh tingkat pendidikan, pendapatan, dan harga, maka frekuensi pembelian ayam broiler -0,191. Koefisien regresi tingkat pendidikan sebesar 0,02 menyatakan bahwa setiap penurunan 1 tahun tingkat pendidikan akan menurunkan frekuensi pembelian ayam broiler sebesar 0,02 satuan, koefisien regresi pendapatan sebesar $0,0000004821=4,821 \times 10^{-7}$ menyatakan bahwa setiap penambahan 1 satuan pendapatan, konsumen akan menaikkan frekuensi pembelian ayam broiler sebesar 4,281 x 10-7, dan koefisien regresi harga ayam broiler sebesar 0,00002713 =2,713 x 10-5 menyatakan bahwa setiap penambahan 1 satuan harga ayam broiler akan menaikkan keputusan pembelian sebesar $2,713 \times 10^{-5}$.

Tabel tersebut juga menunjukkan hasil uji $\mathrm{T}$ yaitu untuk melihat pengaruh setiap variabel bebas terhadap variabel terikat. Nilai Thitung variabel tingkat pendidikan sebesar 0,697 dan nilai Ttabel adalah 2,024 ( $\alpha=0,05)$. Karena nilai Thitung lebih kecil dari nilai Ttabel $(-0,697<2,024)$ dengan nilai signifikansi sebesar $(0,490>0,05)$ maka dapat disimpulkan bahwa tingkat pendidikan tidak memberikan pengaruh yang signifikan terhadap frekuensi 
pembelian ayam broiler. Nilai Thitung variabel pendapatan lebih besar dari nilai Ttabel $(3,137>2,024)$ dengan nilai signifikansi sebesar $(0,003<0,05)$ maka dapat disimpulkan bahwa pendapatan memberikan pengaruh yang signifikan terhadap frekuensi pembelian ayam broiler. Dan nilai Thitung variabel harga ayam lebih kecil dari nilai Ttabel $(1,7<2,024)$ dengan nilai signifikansi sebesar $(0,097>0,05)$ maka dapat disimpulkan bahwa harga ayam tidak memberikan pengaruh yang signifikan terhadap frekuensi pembelian ayam broiler di Desa Gareccing Kecamatan Sinjai Selatan Kabupaten Sinjai.

Tabel 6. Hasil Analisis Regresi Linear Berganda Faktor-faktor yang Mempengaruhi Pembelian Ayam Buras di Desa Gareccing Kecamatan Sinjai Selatan Kabupaten Sinjai

\begin{tabular}{|c|c|c|c|c|}
\hline Variabel & $\begin{array}{c}\text { Koefisien } \\
\text { Regresi }\end{array}$ & $\mathrm{T}_{\text {Hitung }}$ & Nilai Signifikansi & Keterangan \\
\hline Tingkat Pendidikan & 0,015 & 0,359 & 0,721 & Tidak Signifikan \\
\hline Pendapatan & 0,0000005034 & 3,219 & 0,003 & Signifikan \\
\hline Harga & 0,00005188 & $-5,164$ & 0,000 & Signifikan \\
\hline $\mathrm{R}^{2}$ & $=0,432$ & & & \\
\hline Constanta & $=4,959$ & & & \\
\hline Adjusted R Square & $=0,387$ & & & \\
\hline$F_{\text {Hitung }}$ & $=9,633$ & $\mathrm{~F}_{\text {Tabel }}$ & $=2,859$ & \\
\hline $\mathrm{T}_{\text {Tabel }}$ & $=2,026$ & & & \\
\hline
\end{tabular}

Sumber : Data Primer, 2016.

Berdasarkan hasil analisis regresi pada Tabel 6. di atas, maka dapat dibentuk suatu persamaan regresi linier berganda sebagai berikut:

$$
\mathrm{Y}=4,959+0.015 \mathrm{X}_{1}+0,0000005034 \mathrm{X} 2+0,00005188 \mathrm{X} 3
$$

Pada persamaan regresi di atas diperoleh nilai konstanta sebesar 4,959. Hal ini menunjukkan bahwa jika tidak ada pengaruh tingkat pendidikan, pendapatan, dan harga, maka frekuensi pembelian ayam buras sebesar 4,959. Koefisien regresi tingkat pendidikan sebesar 0,015 menyatakan bahwa setiap pertambahan 1 tahun tingkat pendidikan akan menaikkan frekuensi pembelian ayam broiler sebesar 0,015 satuan, koefisien regresi pendapatan sebesar $0,0000005034=5,034 \times 10^{-7}$ menyatakan bahwa setiap penambahan 1 satuan pendapatan konsumen akan menaikkan frekuensi pembelian ayam buras sebesar $5,034 \times 10^{-7}$, dan koefisien regresi harga ayam buras sebesar 0,00005188 $=5,188 \times 10^{-5}$ 
menyatakan bahwa setiap penambahan 1 satuan harga ayam buras akan menaikkan keputusan pembelian sebesar 5,188 x 10-5.

Tabel tersebut juga menunjukkan hasil uji $\mathrm{T}$ yaitu untuk melihat pengaruh setiap variabel bebas terhadap variabel teriakat. Nilai Thitung variabel tingkat pendidikan sebesar 0,359dan nilai Ttabel adalah 2,026 ( $\alpha=0,05)$. Karena nilai Thitung lebih kecil dari nilai Ttabel $(-0,697<2,026)$ dengan nilai signifikansi sebesar $(0,72>0,05)$ maka dapat disimpulkan bahwa tingkat pendidikan tidak memberikan pengaruh yang signifikan terhadap frekuensi pembelian ayam buras. Nilai Thitung variabel pendapatan lebih besar dari nilai Ttabel $(3,219>2,026)$ dengan nilai signifikansi sebesar $(0,003<0,05)$ maka dapat disimpulkan bahwa pendapatan memberikan pengaruh yang signifikan terhadap frekuensi pembelian ayam broiler. Dan, nilai Thitung variabel harga ayam lebih kecil dari nilai Ttabel jika diuji dari arah kiri $(-5,164<-2,024)$ dengan nilai signifikansi sebesar $(0,000<0,05)$ maka dapat disimpulkan bahwa harga ayam memberikan pengaruh yang signifikan terhadap frekuensi pembelian ayam buras Desa Gareccing Kecamatan Sinjai Selatan Kabupaten Sinjai.

Untuk mengetahui persentase sumbangan pengaruh variabel bebas secara bersamasama terhadap variabel terikat, yakni frekuensi pembelian ayam broiler $\left(\mathrm{Y}_{1}\right)$ dan frekuensi pembelian ayam buras $\left(\mathrm{Y}_{2}\right)$ maka digunakan koefisien determinasi. Menurut Santoso (2001), bahwa untuk analisis regresi dengan lebih dari dua variabel bebas maka koefisien determinasi yang digunakan adalah nilai Adjusted $R$ Square. Berdasarkan hasil analisis diperoleh koefisien determinasi dari model yaitu 0,544 atau 54,4\% yang berarti bahwa kemampuan model untuk menjelaskan variabel pembelian ayam broiler $\left(\mathrm{Y}_{1}\right)$ adalah sebesar $54,4 \%$. Sisanya sebesar 45,6\% dijelaskan oleh variabel lain yang tidak dimasukkan dalam model. Sedangkan persentase pengaruh variabel bebas secara bersama-sama terhadap variabel terikat yakni frekuensi pembelian ayam buras $\left(\mathrm{Y}_{2}\right)$ diperoleh koefisien determinasi sebesar 0,387 atau 38,7\% yang berarti bahwa kemampuan model untuk menjelaskan variabel pembelian ayam buras $\left(\mathrm{Y}_{2}\right)$ adalah sebesar 38,7\%. Sisanya sebesar 61,3\% dijelaskan oleh variabel lain yang tidak dimasukkan dalam model.

Selanjutnya, untuk mengetahui pengaruh variabel bebas terhadap variabel terikat secara bersama-sama maka dilakukan uji F. Berdasarkan Tabel 5, nilai Fhitung sebesar 17,715 dan nilai Ftabel sebesar 2,024. Karena nilai Fhitung > Ftabel $(17,715>2,024)$, maka dengan demikian variabel bebas (tingkat pendidikan, pendapatan, dan harga ayam) secara bersama memberikan pengaruh yang nyata terhadap frekuensi pembelian ayam broiler $\left(\mathrm{Y}_{1}\right)$. Hal ini 
berarti bahwa model layak dan dapat digunakan untuk analisis selanjutnya. Hal yang sama, hasil analisis uji F pada pengaruh variabel bebas terhadap variabel terikat frekuensi pembelian ayam buras $\left(\mathrm{Y}_{2}\right)$ dapat dilihat pada Tabel 6. Pada tabel tersebut menunjukkan Fhitung > Ftabel $(9,633>2,026)$, bahwa variabel bebas (tingkat pendidikan, pendapatan, dan harga ayam) secara bersama memberikan pengaruh yang nyata terhadap frekuensi pembelian ayam buras $\left(\mathrm{Y}_{2}\right)$.

\section{KESIMPULAN}

Tingkat pendidikan dan harga ayam tidak memberikan pengaruh yang signifikan terhadap frekuensi pembelian ayam broiler. Namun, pendapatan memberikan pengaruh yang signifikan terhadap frekuensi pembelian ayam broiler di Desa Gareccing Kecamatan Sinjai Selatan Kabupaten Sinjai.Sedangkan faktor-faktor yang memberikan pengaruh signifikan terhadap frekuensi pembelian ayam buras diberikan oleh variabel pendapatan dan harga ayam.

\section{DAFTAR PUSTAKA}

Abidin, Z. 2002. Meningkatkan Produktivitas Ayam Ras Pedaging. Agro Media Pustaka, Jakarta.

Anonim, 2015. Beternak Ayam Pedaging. Aksi Agraris Kanisius, Yogyakarta.

Astawan, M. 2004. Mengapa Kita Perlu Makan Daging. Departemen Teknologi Pangan dan Gizi, IPB. http:/ /www.gizi.net (diakses pada Tanggal 2 Juni 2014).

Burhanudin, A. 2011. Analisis Perilaku Konsumen pada Pembelian Daging Ayam Ras (Broiler Chicken) Di Pasar Traditional dan Pasar Modern Kota Jember. Skripsi. Jurusan Sosial Ekonomi Pertanian, Universitas Jember.

Dwiastuti, A., Shinta R., dan Isaskar. 2012. Ilmu Perilaku Konsumen. Universitas Brawijaya Press, Malang.

Endang, W. 2006. Pengaruh Harga dan Kualitas Produk terhadap Keputusan Pembelian Toyota Kijang (Study Kasus pada PT. Nasmoco Kaligawe Semarang). Universitas Semarang, Semarang.

Engel, J.F. 1994. Perilaku Konsumen. Terjemahan. Budiyanto: Binarupa Aksara, Jakarta.

Fuad, Y. 1992. Usaha Peternakan Ayam Potong (Memproduksi Daging Ayam). Edisi 1. Akademika Persindo, Jakarta.

Hartono, A.H.S. 1999. Beternak Ayam Pedaging Super. CV. Gunung Mas, Pekalongan.

Ita, P. 2013. Analisis Pengaruh Harga, Kualitas Produk, dan Kualitas Layanan terhadap Kepasan Konsumen. Fakultas Ekonomi Universitas Semarang, Semarang

Kotler, P. 2002. Manajemen Pemasaran: Analisis Perencanaan, Implementasi, dan Pengendalian. Salemba Empat, Jakarta.

Lamb, W. C. 2000.Pemasaran Buku 1. PT. Salemba Emba Patria, Jakarta.

Lutfiah, S. 2006. Analisis Perilaku konsumen pada Pembelian Daging Ayam di Kabupaten Jember. Skripsi. Fakultas Pertanian Universitas Jember. Jember. 
Rasyaf, M. 1998. Beternak Ayam Kampung. Penebar Swadaya, Jakarta.

Sarwono. B. 1996. Beternak Ayam Buras Pedaging dan Petelur. Edisi Revisi, Jakarta.

Simamora, B. 2004. Panduan Riset Perilaku Konsumen. Gramedia Pustaka Utama, Jakarta.

Sugiyono. 2000. Statistika Untuk Penelitian. Alfabeta, Bandung.

Sumarwan,U. 2002. Perilaku Konsumen: Teori dan Penerapannya dalam Pemasarannya. Ghalia Indonesia, Jakarta.

Sunarto. 2006. Perilaku Konsumen. Penerbit Amus, Yogyakarta.

Supraptini, M.S. 1985. Pengkajian Sifat-Sifat Produksi Ayam Kampung serta Persilangannya dengan Rhode Island Red. Disertasi. Institut Pertanian Bogor, Bogor.

Umar, H. 2003. Riset Perilaku Konsumen Jasa. Gramedia Pustaka Utama, Jakarta. 